\title{
BULLSNAKE ENJOYING A MEAL
}

\section{TERA EDKINS}

M. Sc. Candidate, Department of Biology

Univerisity of Regina/Royal Saskatchewan Museum

email: tedkins99@gmail.com

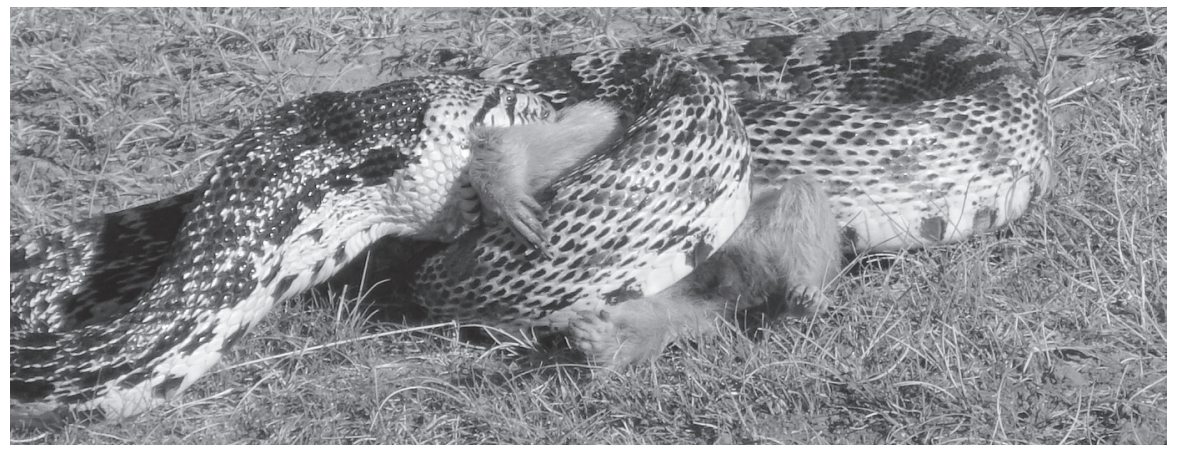

The bullsnake (Pituophis catenifer sayi) pictured is enjoying a large ground squirrel as his meal in pasture in the Big Muddy Valley, SK. Bullsnakes are the largest snake species in Canada, with this particular individual measuring $172 \mathrm{~cm}$ (5.6 feet). Bullsnakes are constrictors, meaning that they use their powerful bodies to suffocate their prey, which typically consists of ground squirrels and other rodents as depicted here. Though they are large in size, very little is known about bullsnake populations in Canada. So little, in fact, that the bullsnake is considered "Data Deficient" by the Committee on the Status of Endangered Wildlife in Canada. ${ }^{1}$ This status means that there is insufficient information to determine whether bullsnakes are at risk of extirpation in Canada. Recent research efforts in Saskatchewan's Frenchman River Valley have shown that bullsnakes move extensively between overwintering dens and summer habitat, requiring much more space to carry out their lifecycle than previously suspected. ${ }^{2,3}$

1. COSEWIC (2002). Bullsnake Pituophis catenifer sayi. www.cosewic.ca.

2. Martino JA, Poulin RG, Parker DL, Somers CM (2012) Habitat selection by grassland snakes at northern range limits: implications for conservation. The Journal of Wildlife Management 76:759-767.

3. Gardiner LE, Somers CM, Parker DL, Martino JA, Poulin RG (2013) Balancing the dumbbell: summer habitats need protection in addition to winter dens for northern snake communities. The Journal of Wildlife Management 77:975-982. 